\title{
Perceived Service Quality: The Effects of Work Stress, Competence, Motivation and Mediating Role of Manager Performance
}

\author{
Mariana Tenreng \\ University of East Indonesia, Makassar
}

\begin{abstract}
This study was designed to test and analyze empirically the mediation role of manager performance in explaining the effect of work stress, competence, and work stress on perceived service quality (Servqual). The population in this research is the Manager of banking in the city of Makassar. Convenience sampling techniques used by the number of samples as much as 95 Manager. The data were analyzed using Warp PLS 5.0. The results showed a low level work stress in opposite directions but significantly to increase manager performance and perceived Servqual. That the manager who had low levels of stress in practice still can improve manager performance and perceived Servqual they create. Creation of high performance manager also caused due to competence that owned manager who ultimately can improve the perceived Servqual. In contrast to the work motivation, that work motivation is high capable of improving manager performance but in practice work motivation cannot increase perceived Servqual role of mediation manager performance are not able to explain the effect of work stress, competence and work motivation, that manager performance does not play an important role in improving the perceived service quality.
\end{abstract}

Keywords: work stress, competence, motivation, manager performance, Perceived service quality

\section{BACKGROUND TO RESEARCH}

The study of service quality has become interesting topics by practitioners and researchers in the last few years which generally use the construct service quality. As a critical measure of organizational performance, service quality is an important measure in marketing in general (Jensen \& Markland, 1996). Service quality often noted as an important requirement to establish and maintain satisfactory relationships with customers. In this way, the association between performance and service quality has emerged as a strategic and significant topic (Bolton \& Drew, 1991; Cronin \& Taylor, 1992; Taylor \& Baker, 1994). In general, the results of previous studies indicate that service quality is an important indicator for customer satisfaction (Spreng \& Mackoy, 1996). More than a decade ago, Parasuraman et al. (1985) initiated the service quality research. Unlike the manufacturing industry product quality can be easily assessed, service quality in the field of services is very abstract and difficult to understand creating barriers in measuring and defining it. Briefly, Parasuraman et al. (1985) describes servqual as a function of customer expectations, that servqual as the gap between customer expectations and how their perceptions of the services they receive (Parasuraman et al., 1988). At first service quality identified through ten determinants, include; tangibles; reliability; responsiveness; competency; courtesy; communication; credibility; security; access; and understanding the customer (Parasuraman et al., 1985). Then in subsequent studies (Parasuraman et

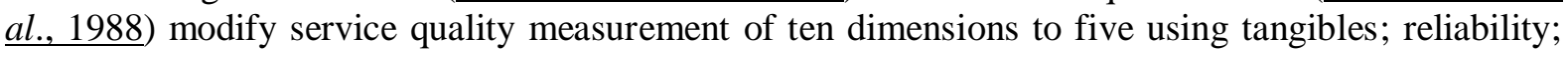
responsiveness; assurance; and empathy. service quality accordance with customer expectations can only be created with the creation of competitive advantage gained through the advantages of human resources that are essential to the success of the banking (Boselie \& Wiele, 2002; Vouzas, 2006). The conditions proved that human resource management strategies are considered essential to the achievement of individual and organizational performance (Boon et al., 2007). Many studies conducted so far were analyzed Servqual using the perception of consumers and employees, whereas the service organization's success is largely determined by the manager. The achievement of organizational results and performance in general building issues have become very popular among researchers in the field of business while the performance of employees in particular is considered key outcomes of individuals in certain contexts, including the context of the financial services and banking (Gabbott \& Hogg, 1997). 
In this context, employees are at the forefront of banks that are expected to play an important role in providing high quality services, promote the company's image and improve customer satisfaction (LeBlanc \& Nguyen, 1988 ; Lewis \& Gabrielsen, 1998 ; Yavas et al., 2003), Employee performance becomes more important especially in the context of the quality of services offered (Kotler \& Keller, 2006). The idea of human capital leads to improved performance on any particular organization services. The implication, the issues of motivation and job stress are important aspects of employee service and performance. Intrinsic motivation plays an important role in creating the best talent for employees (Zucker et al., 1994). The theory needs (Alderfer, 1969) was adopted to investigate the impact of the results of the implementation work as individual performance needs theory is regarded as one of the right way to understand the motivations (Aram \& Piraino, 1978).

The assumption is that certain needs are the major driving force for the motivation of employees in improving their work performance. Identification of specific needs and understanding of the nature of the employee requires insight in understanding the behavior associated with the work so as to create job performance and also servqual (Arnolds \& Boshoff, 2002). In addition to previous research (Alderfer Theory) shows a multidimensional perspective has not succeeded in highlighting the key link between motivation and performance according to social psychology (Amabile et al, 1994). The challenges faced by organizations active in the field of services today is an interesting new service users and maintain the loyalty of service users. Several empirical studies indicate that it is more profitable to retain customers than to get new customers (Hogan et al., 2003; Lee-Kelley et al., 2003). Empirical evidence suggests that the causality between job stress, competence and motivation on the individuals performance and service quality (Dhania 2012; Abdullah, 2012; Arshadi \& Damiri, 2013; Yozgat et al., 2013). Research conducted in the analysis of work stress proves that work stress is not significant effect on the work performance (Dhania, 2012). A high level of job stress is dominated by Men than Women; work-related stress is negative and not significant to the work performance (Yozgat et al., 2013). And a negative correlation was not significant effect between work stress and individuals performance (Arshadi \& Damiri, 2013). Inconsistency findings in analyzing the effect of work stress on individual performance, that there is a significant relationship between job stresses with individual performance (Abdullah, 2012).

Other factors that affect the performance of the individual is an individual's competence, competence is a characteristic that stands out in individual self into ways of behaving and thinking in all situations, and lasts over a long period of time. Competence refers to a person's performance in a job that can be seen from the thoughts, attitudes, and behaviors, (Spencer \& Spencer, 1993). Age and work experience is positively correlated with the competence (Numminen et al., 2013). Competence has a positive and significant effect on the individual performance (Bendoly \& Prietula 2008). A competence of the individual in carrying out its duties and responsibilities has a significant effect on individual performance (Bartram, T. \& Casimir, G 2007; Widyatmini W. \& Judge L., 2011). High motivation resulted in increasing the performance of the individual (Arnolds \& Boshoff, 2002). Motivation as, stimulation and morale of individuals originating from inside or from outside to carry out work activities are very important in improving the performance of individuals. Motivation is the desire contained in an individual who stimulated him to take action or something that becomes the basis or reason for someone to behave (Usman, 2006). Individual work motivation has a positive significant effect on the individual performance (Bartram T. \& Casimir G., 2007; Judge, 2012).

Greenberg \& Baron (1997: 65) mention that the attitudes associated with the work itself (job-related attitudes) that employee motivation to the organization that hired in improving performance. Performance plays an important role in explaining the services, as performance serves as a symbol of quality and value to consumers. One important attribute is the individual performance in interacting with the service users in delivering quality services. Individual performance has a significant effect on perceived quality, and value (Hartline, MD, \& Jones, KC, 1996). His study aimed to explore the application of Scale Service Quality in the context of public services in Romania provides evidence that the gap (dissatisfaction on service quality) explained through the largest dimension of tangibles followed by the dimensions of responsiveness and reliability dimension (Purcarea et al., 2013).

Inconsistency findings prove that the service quality in the health sector on infrastructure indicators, administrative procedures, safety, and social responsibility) no significant impact on user satisfaction (Padma et al., 2010). At the Courant more to do in the hospitality industry provides evidence that the employee's performance is reflected through attitudes, motivation and behavior of employees a 
significant negative effect on the quality of hotel services (Bodouva JJ, 2009). The description above raises the problem whether the mediating effect the performance of the manager can explain the effect of stress, competence and motivation on the banking services

\section{Conceptual Background and Review of Past Literature}

\subsection{Work Stress}

Work stress is defined as threatening condition, pressing, and unpleasant for the individual. More specifically, stress is a physical and psychological reaction to the changes experienced by the individual. Psychic reaction may be the attitude of withdrawal and the formation of ego defense mechanisms. The changes are a form of individual adaptation to interact with the environment (Tyrer, 1984). Stress in the workplace is a condition that is often found in the works manager. Manager in the banking profession is highly vulnerable to the stress, the condition is triggered due to the demands of the organization and its interaction with the job that often bring conflict over what to do.

The concept of stress is very complex, due to the diversity of reactions and feelings to stress (Kahn \& Byosiere, 1992). Relationship between job stress and performance as an emotional intelligence is moderating variable. The results of hierarchical regression analysis provides evidence that the work stress-related negative and not significant to the performance of the employee (Yozgat et al., 2013). Other evidence shows that job stress significantly influence customers' willingness to make repeat purchases due to high quality of services provided to customers (Netemeyer et al., 2005).

\subsection{Manager Competence}

Competence is defined as characteristics required by a holder of office in order to carry out the office well, or it could also mean the characteristics / traits a person who is easily seen, including knowledge, skills, and behaviors that allow it to perform (Byars \& Rue, 1997). Competence consists of the unique properties of each individual are expressed in the process of interaction with others in a social context, so it is not just limited to the specific knowledge and skills or standards of performance expected and the behavior shown. So competencies include attitudes, perceptions and emotions and emphasis on personal interaction and social factors (Antonacopoulou \& Gerald, 1996). Constructs preparedness is a reflection of the competence, that the self-directed readiness has a positive and significant on competence, so that it can be concluded that the self-directed readiness is a predictor of competence (Yang \& Jiang, 2014). In other parts of the human capital in the organization referred to as a job competence, competence of workers has an effective impact on the performance of the work (Hsu, 2008). While the relevance of competence in improving the quality of service, proven competence have a significant influence on the quality of service (Dagger et al., 2007).

\subsection{Work Motivation}

Motivation is the willingness to issue a high level of effort toward organizational goals are individual needs, of the three elements of this definition is an attempt, the organization's goals and needs. So motivation is an effort that is in a person to meet their needs in order to achieve organizational goals (Robbins, 1996: 198). The most efficient way to perform repetitive work and motivate employees is the intensification of the wage system, the more that is produced by the greater employee wages. This model is too simplistic because it assumes that the motivation manager focused on one factor is money, thus it can be concluded that the purpose of motivation encourages a person to be able to do the work optimally in accordance with its intended purpose (Stoner et al., 1996: 136).

The relationship between motivation and performance are positive for employees who have high motivation will produce peak performance. This means, the higher the motivation, the higher employee performance (Armstrong, 2003). The empirical evidence points out that the motivation on the performance shown in studies conducted Judge (2012) that motivation have a significant impact on employee performance. Motivation addition to an effect on the performance, we found that high motivation can improve the quality of the waitress, as shown in research Chen \& Kao (2014), that the problems in providing services become more complex and diverse, proactive behavior is becoming more important as a determinant of organizational success. evidence that the climate of low service provides no significant effect on the quality of services provided, the emergence of high intrinsic motivation of the workers themselves have a positive and significant effect on the service quality. 


\subsection{Manager Performance}

Rate the performance of managers in an organization in order to develop human resources is an activity that can improve organizational decisions and provide feedback to managers about their activities. Performance is often called the performance or result (Cash \& Fischer, 1987) which means that what has been produced by individuals. Individual performance as the quality and quantity of the achievement of the tasks, whether committed by individuals, groups and companies (Clugston et al., 2000). Individual performance is defined as the degree to which someone in performing job duties is called the level of performance (Vroom, 1964).

Effects of individual performance with the service quality can be explained that the service provided on an individual basis is an important part in creating a service quality process. The statement explained that the employee's performance is reflected through attitudes, motivation and behavior of employees a negative and significant effect on service quality (Bodouva, JJ, 2009). Research conducted in Contextual banks to provide evidence that there are significant differences between the performance manager and employee performance, that performance of managers and employees based perspective (high-performance work systems / HPWSs) positively associated with performance of the public service of individuals through the intermediary of the capital employee and perceived organizational support and positively related to the individual performance of service then the overall performance of individual services (knowledge-intensive) significantly affects on customer satisfaction and service quality in banking (Liao et al., 2009).

\subsection{Servqual in Banking}

The paradigm shift to service quality, today experts agree that the idea of the service quality is determined by the customer or consumer. Quality management is a set of practices defined by the theoreticians and practitioners of quality. Theorist's quality produce thorough philosophical content of the quality and practitioners now being filled in the details on how to do and improve quality. The term quality increasingly requires understanding the process or device that is comprehensive in terms of the organization so that it can be implemented. Service quality is expressed as votes or global attitudes regarding the superiority of service.

The difference between reality and expectations of the customers on the services they receive or earn. Hope is the desire of the customers of the services that may be offered banking (Parasuraman et al., 1988). Quality of service can be determined by comparing the perceptions of customers for the service, which obviously they have received or acquired by the actual service they expect and want. If the reality is greater than expected, the quality of service can be said, but if the reality was less than expected, the service can be said to be inferior; when the reality is equal to expectations, then called satisfactory service (Tjiptono, 2005: 25). The concept of service quality is generally defined as the difference between the expected service and perceived service (Parasuraman et al., 1988).

Conceptualization of service quality is rooted in the theory disconfirmation of expectations, so the evaluation result of the quality of service is a comparison of perceptions of services received prior to the services that should be accepted. The concept of quality of service can be represented in different ways depending on the aspects and methods or approaches used (Choi et al., 2004). In the banking industry, the service quality plays an important role in improving customer satisfaction. Service quality in the bank plays an important role in improving customer satisfaction. There is a reciprocal relationship between the bank and the customer in building customer loyalty, so that it can provide a competitive advantage in the banking sector (Teas, 1993). Many studies have provided the basis for financial institutions to enhance customer satisfaction (Wilkinson et al., 1991). Implementation of servqual in the banking industry, by analyzing the quality of service on the dimensions of compliance, Assurances, reliability, tangibles, empathy and responsiveness, it is evident that the most important factor in creating a quality service demonstrated through empathy (Ali, M \& Raza, SA 2015) .

\section{MeThodology}

Job stress measurement model used to develop measurement Arshadi \& Damiri (2013), which is reflected through the work conflict, workload, working time, and the characteristics of the task. On the measurement of competence manager used measurements, which include: knowledge, skill, and self-concept (Dagger et al., 2007; Yang, GF, \& Jiang, XY, 2014). In other sections analyzed motivation measured by extrinsic motivation and intrinsic motivation (Robbins, 2003). Performance Manager is an intervening variable that is measured by the quantity of work, quality of work, and the 
accuracy of the Time (Heidjrachman \& Husnan, 2000). SERVQUAL measurement consists of five dimensions such as; tangibles, empathy, reliability, responsiveness, and Assurances (Parasuraman et al., 1988; Padma et al., 2010).

The questionnaire used was changed and replaced carefully and given to the 26 commercial banks in Makassar (Indonesia), each bank is represented by 4 Manager, so that the whole questionnaire distributed amounted to 104 questionnaires, there are 9 of them are disabled so it can not used for analysis. All the items in the instrument were translated into English, whereas the content validity was confirmed by academics that are deemed to have expertise in the field of organizational behavior and marketing research. Therefore, it was confirmed that all the items are relevant and easy to understand instruments. A 5-point Likert scale ranging from (1) 'strongly disagree', (2) 'disagree', (3) 'neutral', (4) 'agree' and (5) 'strongly agree' was used to measure the perception about the variable analysis. Sample data are used and data collection is done via survey method. The data collection is based on a 5-point Likert scaling questionnaire adopted in the previous literature. This research was conducted in October-December 2015 and a non-probability sampling technique (convenience sampling) was applied.

\section{ESTIMATIONS AND RESUltS}

Table1. Profile of respondents.

\begin{tabular}{|c|c|c|}
\hline Demographic items & Frequency & Percentile $(\%)$ \\
\hline \multicolumn{3}{|l|}{ Gender } \\
\hline Male & 81 & 85 \\
\hline Female & 14 & 15 \\
\hline \multicolumn{3}{|l|}{ Marital status } \\
\hline Single & 6 & 6 \\
\hline Married & 89 & 94 \\
\hline \multicolumn{3}{|l|}{ Age } \\
\hline $20-30$ & 4 & 4 \\
\hline $31-40$ & 19 & 20 \\
\hline $41-50$ & 52 & 55 \\
\hline 50 and above & 20 & 21 \\
\hline
\end{tabular}

Source: Authors' Estimation.

Profile of respondents in our study is presented in Table 1. This table gives an overall picture of the sample of respondents. In this table, $85 \%$ of respondents were male and $15 \%$ of respondents were female. Most of the respondents were married (94\%), while 6\% are still single. During data collection, the span of the respondents were aged 41-50 (55\%), followed by ages 50 and above (21\%), 31-40 years (20\%), and those aged 20-30 (4\%). This study uses variance-based technique SEM (SEM-PLS) with 5.0 WarpPLS developed Kock (2010). In contrast with the previous software, using WarpPLS 5.0 nonlinear can identify relationships between latent variables and correct the path coefficient value.

\subsection{Goodness of Fit Model}

P-value for the Average path coefficient (APC) and the ARS and the R-squared value Average (ARS) must be $<0.05$ or significant meaning. Additionally Average full collinearity VIF (AFVIF) should be $<5$.

Table2. Model fit and quality indices

\begin{tabular}{|l|l|l|}
\hline & Model 1 & Model 2 \\
\hline APC & $0.225, \mathrm{P}=0.005$ & $0.235, \mathrm{P}=0.004$ \\
\hline ARS & $0.303, \mathrm{P}<0.001$ & $0.285, \mathrm{P}<0.001$ \\
\hline AFVIF & $1.272<5$ & $1.216<5$ \\
\hline
\end{tabular}

Source: Authors' Estimation.

The result showed that the model goodness of fit criteria has been met (Kock, 2011).

\subsection{Measurement Model}

Measurement models or outer models that construct validity and reliability. This output is used investigators to report the results of testing the convergent validity of the measurement instruments. 
Table3a. Combined Loading and cross-loadings (Model 1)

\begin{tabular}{|l|l|l|l|l|l|l|l|l|}
\hline & W_stres & Compete & Motivat & Man_Per & Servqua & Type (a & SE & P value \\
\hline Ws1 & $(0.764)$ & -0.149 & 0.102 & 0.078 & 0.143 & Reflect & 0.083 & $<0.001$ \\
\hline Ws2 & $(0.868)$ & -0.022 & 0.134 & -0.015 & 0.119 & Reflect & 0.081 & $<0.001$ \\
\hline Ws3 & $(0.736)$ & 0.163 & -0.022 & -0.017 & -0.149 & Reflect & 0.084 & $<0.001$ \\
\hline Ws4 & $(0.418)$ & 0.012 & -0.323 & -0.062 & -0.176 & Reflect & 0.091 & $<0.001$ \\
\hline Comp1 & -0.061 & $(0.665)$ & 0.041 & -0.416 & 0.231 & Reflect & 0.085 & $<0.001$ \\
\hline Comp2 & 0.058 & $(0.910)$ & -0.059 & 0.111 & -0.013 & Reflect & 0.080 & $<0.001$ \\
\hline Comp3 & -0.013 & $(0.918)$ & 0.028 & 0.191 & -0.155 & Reflect & 0.079 & $<0.001$ \\
\hline Mot1 & 0.089 & 0.070 & $(0.757)$ & 0.194 & -0.162 & Reflect & 0.083 & $<0.001$ \\
\hline Mot2 & -0.089 & -0.070 & $(0.757)$ & -0.194 & 0.162 & Reflect & 0.083 & $<0.001$ \\
\hline Perf1 & -0.172 & 0.194 & 0.252 & $(0.726)$ & -0.398 & Reflect & 0.084 & $<0.001$ \\
\hline Perf2 & 0.057 & -0.148 & -0.107 & $(0.925)$ & 0.070 & Reflect & 0.079 & $<0.001$ \\
\hline Perf3 & 0.087 & -0.005 & -0.102 & $(0.829)$ & 0.271 & Reflect & 0.081 & $<0.001$ \\
\hline Servqua & 0.115 & 0.028 & -0.175 & 0.135 & $(0.684)$ & Reflect & 0.085 & $<0.001$ \\
\hline Servqua & -0.098 & 0.278 & 0.019 & 0.179 & $(0.653)$ & Reflect & 0.086 & $<0.001$ \\
\hline Servqua & -0.141 & -0.016 & -0.046 & 0.053 & $(0.801)$ & Reflect & 0.082 & $<0.001$ \\
\hline Sevqual & -0.117 & -0.225 & 0.257 & -0.409 & $(0.685)$ & Reflect & 0.085 & $<0.001$ \\
\hline Servqua & 0.245 & -0.046 & -0.044 & 0.040 & $(0.726)$ & Reflect & 0.084 & $<0.001$ \\
\hline
\end{tabular}

Source: Authors' Estimation.

In Table 3a Combined Loading and cross-loadings are still construct convergent validity $<0.70$ (pvalue $<0.05$ ) and should be removed from the model, as shown in Table $3 \mathrm{~b}$.

Table3b. Combined Loading and cross-loadings (Model 2)

\begin{tabular}{|l|l|l|l|l|l|l|l|l|}
\hline & W_stres & Compete & Motivat & Man_Per & Servqua & Type $(\mathrm{a}$ & SE & P value \\
\hline Ws1 & $(0.784)$ & -0.076 & 0.033 & 0.075 & 0.079 & Reflect & 0.082 & $<0.001$ \\
\hline Ws2 & $(0.881)$ & -0.011 & 0.103 & -0.058 & 0.142 & Reflect & 0.080 & $<0.001$ \\
\hline Ws3 & $(0.766)$ & 0.095 & -0.080 & 0.020 & -0.208 & Reflect & 0.083 & $<0.001$ \\
\hline Comp2 & 0.032 & $(0.953)$ & -0.043 & -0.060 & 0.065 & Reflect & 0.079 & $<0.001$ \\
\hline Comp3 & -0.032 & $(0.953)$ & 0.043 & 0.060 & -0.065 & Reflect & 0.079 & $<0.001$ \\
\hline Mot1 & 0.116 & 0.019 & $(0.757)$ & 0.222 & -0.076 & Reflect & 0.083 & $<0.001$ \\
\hline Mot2 & -0.116 & -0.019 & $(0.757)$ & -0.222 & 0.076 & Reflect & 0.083 & $<0.001$ \\
\hline Perf1 & -0.170 & 0.220 & 0.264 & $(0.726)$ & -0.392 & Reflect & 0.084 & $<0.001$ \\
\hline Perf2 & 0.059 & -0.144 & -0.115 & $(0.925)$ & 0.072 & Reflect & 0.079 & $<0.001$ \\
\hline Perf3 & 0.084 & -0.032 & -0.103 & $(0.829)$ & 0.264 & Reflect & 0.081 & $<0.001$ \\
\hline Servqua & -0.206 & 0.095 & -0.000 & -0.020 & $(0.854)$ & Reflect & 0.081 & $<0.001$ \\
\hline Servqua & 0.206 & -0.095 & 0.000 & 0.020 & $(0.854)$ & Reflect & 0.081 & $<0.001$ \\
\hline
\end{tabular}

Source: Authors' Estimation.

The Results in Table 3b shows that the convergent validity criteria in model 1 have not been fulfilled and to model 2 fulfilled having already qualified, convergent validity of $>0.70$ and significant ( $p$ value <0.05). (Hair et al., 2013).

\subsection{Diskriminan Validity}

Discriminant validity test demonstrated through results output latent variable correlations. This output reports the correlation coefficient between the latent variables. The criteria used are the square roots, average variance extracted (AVE) is a column diagonal bracketed must be higher than the correlation between latent variables in the same column (above or below) (Sholihin, M \& Dwi R, 2013).

Table4. Correlations among l.vs. with sq. rts. of AVEs (Model 2)

\begin{tabular}{|l|l|l|l|l|l|}
\hline & W_stres & Compete & Motivat & Man_Per & Servqua \\
\hline W_stre & $(0.854)$ & -0.152 & -0.061 & -0.260 & -0.307 \\
\hline Compe & -0.152 & $(0.953)$ & 0.249 & 0.359 & 0.333 \\
\hline Motivat & -0.061 & 0.249 & $0.757)$ & 0.313 & 0.149 \\
\hline Man_Per & -0.260 & 0.359 & 0.313 & $(0.831)$ & 0.211 \\
\hline Servqu & -0.307 & 0.333 & 0.149 & 0.211 & $(0.854)$ \\
\hline
\end{tabular}

Source: Authors' Estimation. 
The table shows that the discriminant validity has been met, which can be seen from the root of AVE on the diagonal column is greater than the correlation between constructs in the same column. The results of this cross-loading an indication discriminant validity.

\subsection{Reliability Constructs}

Reliability constructs can be seen from the latent variable output coefficient

Table5. Output Latent Variable Coefficient (Model 2)

\begin{tabular}{|l|l|l|l|l|l|}
\hline & W_stres & Compete & Motivat & Man_Per & Servqua \\
\hline R-squared & & & & 0.321 & 0.250 \\
\hline Adj. R-squared & & & & 0.298 & 0.217 \\
\hline Composite reliab. & 0.914 & 0.952 & 0.729 & 0.869 & 0.843 \\
\hline Cronbach's alpha & 0.873 & 0.900 & 0.256 & 0.770 & 0.628 \\
\hline Avg. Var. Extrac & 0.730 & 0.909 & 0.573 & 0.690 & 0.729 \\
\hline Full collin VIF & 1.158 & 1.270 & 1.141 & 1.289 & 1.223 \\
\hline Q-squared & & & & 0.327 & 0.268 \\
\hline
\end{tabular}

Source: Authors' Estimation.

The coefficient of determination using the R-squared value that indicates what percentage of the variance of the construct of an endogenous / criterion can be explained by the construct of the hypothesized effect. The higher the R-squared shows a good model. From the results of the output Latent Variable Coefficient R-squared shows the 0,321 performance means variance manager manager performance can be explained variance of $32.10 \%$ by work stress, competence and work motivation. R-squared of 0.250 servqual construct showed that servqual variance can be explained by $25 \%$ by the variance of manager performance. Reliability composite value and Cronbach alpha reliability have qualified that is $>0.70$. Output above also shows that the Average Variance Extracted $(\mathrm{AVE})>0.50$, which means qualified convergent validity (Sholihin, A \& Dwi R, 2013).

Full collinearity (VIF) is full collinearity test results which include vertical and lateral multikolinearity. Collinearity lateral is collinearity between the latent variables predictor with the criterion. Collinearity lateral often overlooked when can cause the results to be biased. Full collinearity (VIF) in this study was $<3.3$ it indicates that the model is free from problems collinearity vertical, lateral, and commond method bias (Kock, 2013). Q-squared is a measure of non-parametric obtained through the blindfold algorithms and used to study the predictive validity or relevance of a set of latent predictor variables on criterion variables. Output showed Q-squared is greater than zero, namely 0,327 and 0,268 means that the estimated model shows a good predictive validity. Overall, the results of measurement model (outer model) reflective construct have been qualified.

\subsection{Model and Hypothesis Testing}

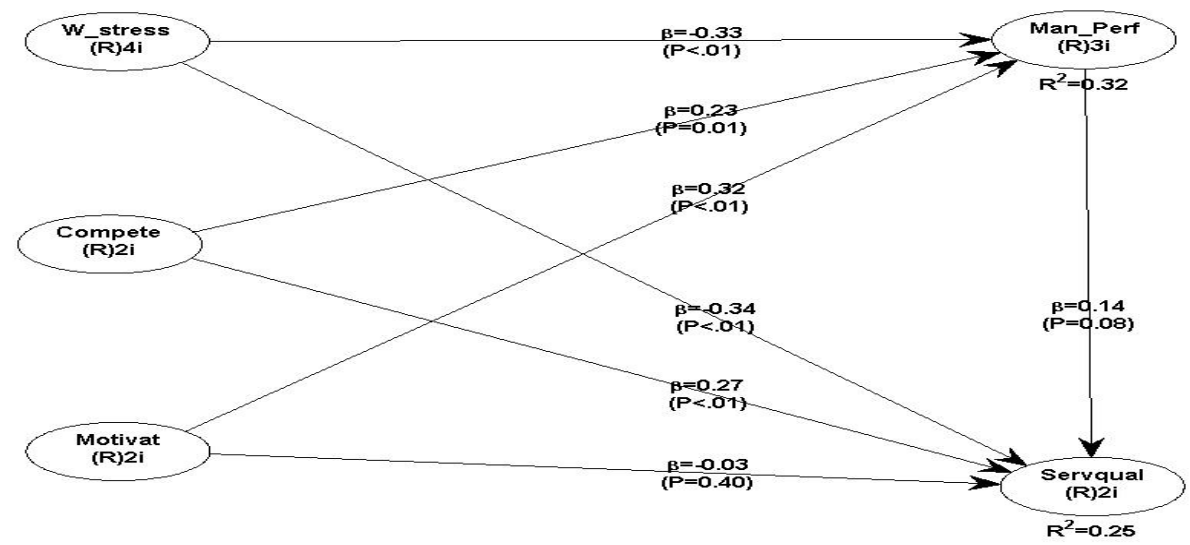

Source: Authors' Estimation

Figure1. Result Modell 
Table6. Path Coeffisient dan P-value (Model 2)

Path coefficients

\begin{tabular}{|l|l|l|l|l|l|}
\hline & W_stres & Compete & Motivat & Man_Per & Servqua \\
\hline W_stres & & & & & \\
\hline Compete & & & & & \\
\hline Motivat & & & & & \\
\hline Man_Per & -0.329 & 0.227 & 0.319 & & \\
\hline Servqua & -0.338 & 0.265 & -0.026 & 0.139 & \\
\hline
\end{tabular}

P values
\begin{tabular}{|l|l|l|l|l|l|}
\hline & W_stres & Compete & Motivat & Man_Per & Servqua \\
\hline W_stres & & & & & \\
\hline Compete & & & & & \\
\hline Motivat & & & & & \\
\hline Man_Per & $<0.001$ & 0.010 & $<0.001$ & & \\
\hline Servqua & $<0.001$ & 0.003 & 0.398 & 0.081 & \\
\hline
\end{tabular}

Source: Authors' Estimation.

\section{$\left(\mathrm{H}_{1}\right)$ Work stress on Manager Performance}

The effect of work stress on Manager Performance can be demonstrated by a standardized path coefficients amounting $-0,329$ negative direction. Standardized path coefficient is negative explain that low stress work tends to degrade manager performance. Then it can be proved with a p-value = $0.001<0.05$. The test results prove that the work stress hypothesis of a significant and negative effect on the manager performance, it can be concluded that the low stress work in the opposite direction but it is significant to improving the manager performance. So the hypothesis $\mathrm{H}_{1}$ work stress has not significant and negative effect on the manager performance partially be accepted or supported by empirical facts. These results partially support the findings of provide evidence that the work stressrelated negative and not significant effect on employee performance (Yozgat et al., 2013)

\section{$\left(\mathbf{H}_{2}\right)$ Competence on Manager Performance}

The effect of competence on manager performance can be demonstrated by a standardized path coefficients of 0,227 with a positive direction. Standardized path coefficient is positive, explaining that the high competence tends to improve performance manager. Then it can be proved with a pvalue $=0,010<0.05$. The test results prove the hypothesis that competence is positive and significant effect on manager performance, it can be concluded that a high competence in the direction of a positive and significant effect on performance improvement manager. So the hypothesis $\mathrm{H}_{2}$ Competence has a positive and significant effect on manager performance can be accepted or supported by empirical facts. This study supports the findings provide evidence that the competence of the workers have an effective impact on the employee performance ( $\underline{\mathrm{Hsu}, 2008)}$.

\section{$\left(\mathrm{H}_{3}\right)$ Work motivation to Manager Performance}

The effect of work motivation on manager performance can be demonstrated by standardized path coefficients of 0,319 with a positive direction. Standardized path coefficient is positive, explaining that work motivation is high tend to improve performance manager. Then it can be proved with a pvalue $=0,001<0,05$. Hypothesis testing results prove that the work motivation has a positive and significant effect on manager performance, it can be concluded that a high competence in the direction of a positive and significant effect on manager performance. So the hypothesis $\mathrm{H}_{3}$ work motivation has a positive and significant effect on manager performance can be accepted or supported by empirical evidence. The effect of motivation on performance is positive because the manager who has a high motivation will produce peak performance. This means, the higher the motivation, the higher the performance of employees. This study supports other empirical fact that the motivation on the performance (Hakim, 2012).

\section{$\left(\mathrm{H}_{4}\right)$ Work Stress on Perceived Service Quality}

The effect of work stress on perceived service quality can be evidenced by standardized path coefficients amounting - 0,338 negative direction. Standardized path coefficient is negative explain that low stress work tends to increase servqual. Then it can be proved with a $p$-value $=0.001<0.05$. The hypothesis results prove that the work stress has a negative and significant effect on perceived 
service quality, it can be concluded that the low stress work in opposite directions but significantly to the improvement of perceived service quality. So the hypothesis $\mathrm{H}_{4}$ work stress has a negative and significant effect on perceived service quality partially can be accepted or supported by empirical facts. These findings support the findings Netemeyer et al. (2005) that the work stress significantly influence customers' willingness to make repeat purchases due to high quality of service.

\section{$\left(\mathrm{H}_{5}\right)$ Competence on Perceived Service Quality}

The effect of competence on perceived service quality can be evidenced by standardized path coefficients of 0,265 with a positive direction. Standardized path coefficient is positive, explaining that the high competence tends to increase servqual. Then it can be proved with a p-value $=0.003<$ 0.05 . The test results prove the hypothesis that competence is positive and significant effect on servqual, it can be concluded that a high competence in the direction of a positive and significant effect on perceived service quality. So the hypothesis $\mathrm{H}_{5}$ competence has a positive and significant effect on perceived service quality can be accepted or supported by empirical facts. This study supports previous research findings that competence has a significant effect on service quality (Dagger et al., 2007).

\section{$\left(\mathbf{H}_{6}\right)$ Work Motivation on Perceived Service Quality}

The effect of work motivation on manager performance can be demonstrated by a standardized path coefficients amounting $-0,026$ negative direction. Standardized path coefficient is negative explained that the low work motivation tends to decrease perceived service quality. Then it can be proved with a $\mathrm{p}$-value $=0,398>0.05$. Hypothesis testing results prove that the work motivation have a negative and insignificant effect on insignificant effect, it can be concluded that the low work motivation opposite direction and insignificant effect on perceived service quality. So the hypothesis $\mathrm{H}_{6}$ work motivation has a positive and significant effect on perceived service quality not acceptable or is not supported by empirical facts. The study refutes previous research findings, that high intrinsic motivation of the workers themselves has a positive influence and significant impact on the quality of service (Chen \& $\underline{\mathrm{KaO}, 2014)}$.

\section{$\left(\mathrm{H}_{7}\right)$ Manager Performance on Perceived Service Quality}

The effect of manager performance on perceived service quality can be evidenced by standardized path coefficients of 0,139 with a positive direction. Standardized path coefficient is positive, explaining that the high performance manager tends to increase perceived service quality. In a study of the statement cannot be proved because the p-value $=0,081>0.05$. Hypothesis testing results prove that the manager performance have a positive and insignificant effect on perceived service quality, it can be concluded that the high performance manager unidirectional positive and insignificant increase in perceived service quality. So the hypothesis $\mathrm{H}_{7}$ manager performance has a positive and significant effect on perceived service quality partially not acceptable or is not supported by empirical facts. These findings refute previous studies that the manager and employee performance significantly affect and quality of banking services (Liao et al., 2009).

\section{$\left(\mathrm{H}_{8}\right)$ Linking Work Stress on Perceived Service Quality. The Mediating Role of Manager Performance}

Results of hypothesis testing and the results Sobel test was done to determine the p-value the indirect effect (the mediating effect of manager performance) that work stress is low it can be done directly improve perceived service quality without the support of manager performance, that manager performance does not act as a mediation in explaining the effect of work stress on perceived service quality. Results of Sobel's test showed that the standard error for mediating effect $=0,036$ (sab), Product path coefficient for mediating effect $=-0,046(\mathrm{ab}), \mathrm{t}$ - value for mediating effect $=-1,260$ (Tab), then p-value for mediating effect, one-tailed $=0,105(\mathrm{Pab})$, and the $\mathrm{p}$-value for mediating effect, two-tailed $=0,210\left(P a b^{\prime}\right)(\underline{\text { Kock, 2013) }}$.

These results explain that the manager performance is insignificant in explaining its role as a mediating effect in explaining the effect of work stress on perceived service quality. Then based Sobel test the performance manager variable is declared not a mediation effect. This means that work stress significant effect on perceived service quality, work stress significantly effect on performance 
manager and performance manager insignificant effect on perceived service quality, so without the support with manager performance, work stress can increase the proven perceived service quality.

\section{$\left(\mathrm{H}_{9}\right)$ Linking Competence on Perceived Service Quality. The Mediating Role of Manager Performance}

Results of hypothesis testing and the results Sobel test was done to determine the p-value the indirect effect (effect mediating role of managerial performance) that competence is high can be made directly improve perceived service quality without the support of manager performance, that manager performance does not act as mediation in describing work stress on perceived service quality. Results Sobel test shows that Sobel's standard error for mediating effect $=0.028$ (sab), Product path coefficient for mediating effect $=0.032(\mathrm{ab})$, the $\mathrm{t}$-value for mediating effect $=1.135(\mathrm{Tab})$, then the $\mathrm{p}$-value for mediating effect, one tailed $=0.130(\mathrm{Pab})$, and the $\mathrm{p}$-value for mediating effect, two-tailed $=0.259\left(\mathrm{Pab}^{\prime}\right)$ ( Kock, 2013) .

These results explain that the manager performance is not significant in explaining its role as a mediating effect in explaining the effect of competence on perceived service quality. Based on Sobel test the performance manager variable is declared not mediation effect. This means a significant effect on perceived service quality, competence significantly effect on manager performance and then manager performance insignificant effect on perceived service quality, so without the support with manager performance, proven competence can be directly increase perceived service quality.

\section{$\left(\mathrm{H}_{10}\right)$ Linking Work Motivation on Perceived Service Quality. The Mediating Role of Manager Performance}

Results of hypothesis testing and the results Sobel test was done to determine the p-value the indirect effect (effect mediating role of managerial performance) that motivation is high cannot directly increase the perceived service quality without the support of manager performance, that manager performance does not act as a mediating role in explaining the effect of work motivation on perceived service quality. Sobel's standard error for mediating effect $=0,035$ (sab), Product path coefficient for mediating effect $=0.044(\mathrm{ab})$, the $\mathrm{t}$-value for mediating effect $=1,252(\mathrm{Tab})$, then the $\mathrm{p}$-value for mediating effect, one tailed $=0,107(\mathrm{Pab})$, and the $\mathrm{p}$-value for mediating effect, two-tailed $=0,214$ (Pab') (Kock, 2013). These results explain that the manager performance insignificant effect in explaining its role as a mediating effect in explaining the effect of work motivation on perceived service quality.

Based on Sobel test the performance manager is not mediating effect. This means that work motivation insignificant on perceived service quality, work motivation significantly effect on manager performance and then performance manager insignificant effect on perceived service quality, so without the support manager performance, work motivation is not proven to increase perceived service quality.

\section{CONClUSION AND RECOMMENDATIONS}

Work stress is low in opposite directions but significantly to the improvement of performance and perceived service quality manager. That the manager who had low levels of stress in practice they can improve performance and perceived service quality manager that they create. The high performance managers also due competence possessed manager that can be ultimately increase the perceived service quality. In contrast to the work motivation, that work motivation is high capable of improving manager performance but in practice work motivation cannot increase perceived service quality role of mediation manager performance are not able to explain the effect of work stress, competence and work motivation, that manager performance does not play an important role in improving the perceived service quality.

Measurement of the construct of the 17 indicators used in the model 1, qualified, convergent validity and significant, only 12 indicators, which can be described as follows, to work stress was measured by indicators of conflict, load, and hours of work; competence is measured by indicators of skill and selfconcept; work motivation measured by indicators of extrinsic and intrinsic motivation; manager performance (quantity, quality, and timeliness). As for the SERVQUAL dimensions measured by reliability and Assurances, so recommended to the researchers continued to consider these constructs to be used in the banking industry. 


\section{ACKNOWLEDGMENT}

This paper provides additional research in analyzing Servqual in the context of banking manager, which has been used in the customers context.

\section{REFERENCES}

[1] Parasuraman, A., Zeithaml, V. A., \& Berry, L. L. (1985). A conceptual model of service quality and its implications for future research. The Journal of Marketing, 41-50. http://dx.doi.org/ $\underline{10.2307 / 1251430}$

[2] Jensen, J. B., \& Markland, R. E. (1996). Improving the application of quality conformance tools in service firms. Journal of Services Marketing, 10(1), 35-55. http://dx.doi.org/10.1108/08876 $\underline{049610147838}$

[3] Bolton, R. N., \& Drew, J. H. (1991). A multistage model of customers' assessments of service quality and value. Journal of consumer research, 17(4), 375-384. http://dx.doi.org/10.1086/ 208564

[4] Cronin Jr, J. J., \& Taylor, S. A. (1992). Measuring service quality: a reexamination and extension. The journal of marketing, 55-68. http://dx.doi.org/10.2307/1252296

[5] Taylor, S. A., \& Baker, T. L. (1994). An assessment of the relationship between service quality and customer satisfaction in the formation of consumers' purchase intentions. Journal of retailing, 70(2), 163-178. http://dx.doi.org/10.1016/0022-4359(94)90013-2

[6] Spreng, R. A., \& Mackoy, R. D. (1996). An empirical examination of a model of perceived service quality and satisfaction. Journal of retailing, 72(2), 201-214. http://dx.doi.org/10.1016/ $\underline{\text { S0022-4359(96)90014-7 }}$

[7] Parasuraman, A., Zeithaml, V. A., \& Berry, L. L. (1988). Servqual. Journal of retailing, 64(1), $12-40$.

[8] Boselie, P., \& Van der Wiele, T. (2002). Employee perceptions of HRM and TQM, and the effects on satisfaction and intention to leave. Managing Service Quality: An International Journal, 12(3), 165-172. http://dx.doi.org/10.1108/09604520210429231

[9] Vouzas, F. (2006). Investigating the link between quality improvement efforts and strategic HRM in selected Greek industrial organizations implementing the new ISO 9000: 2000. Measuring Business Excellence, 10(1). http://dx.doi.org/10.1108/mbe.2006.26710aaf.001

[10] Boon Ooi, K., Abu Bakar, N., Arumugam, V., Vellapan, L., \& Kim Yin Loke, A. (2007). Does TQM influence employees' job satisfaction? An empirical case analysis. International Journal of Quality \& Reliability Management, 24(1), 62-77. http://dx.doi.org/10.1108/02656710710720330

[11] Gabbott, M., \& Hogg, G. (Eds.). (1997). Contemporary services marketing management: A reader. Dryden Press.

[12] LeBlanc, G., \& Nguyen, N. (1988). Customers' perceptions of service quality in financial institutions. International Journal of Bank Marketing, 6(4), 7-18. http://dx.doi.org/10.1108/ eb010834

[13] Lewis, B. R., \& Gabrielsen, G. O. (1998). Intra-organisational aspects of service quality management: the employees' perspective. Service Industries Journal, 18(2), 64-89. http://dx. doi.org/10.1080/02642069800000019

[14] Yavas, U., Karatepe, O. M., Avci, T., \& Tekinkus, M. (2003). Antecedents and outcomes of service recovery performance: an empirical study of frontline employees in Turkish banks. International Journal of Bank Marketing, 21(5), 255-265. http://dx.doi.org/10.1108/ 02652320 $\underline{310488439}$

[15] Kotler, P., \& Keller, K. L. (2006). Marketing management. Analysis, Planning and Control. Prentice Hall. Eaglewood Cliff.

[16] Zucker, L. G., Darby, M. R., \& Brewer, M. B. (1994). Intellectual capital and the birth of US biotechnology enterprises (No. w4653). National Bureau of Economic Research.

[17] Alderfer, C. P. (1969). An empirical test of a new theory of human needs. Organizational behavior and human performance, 4(2), 142-175. 
[18] Aram, J. D., \& Piraino, T. G. (1978). The hierarchy of needs theory: An evaluation in Chile. Revista Interamericana de Psicologia.

[19] Arnolds, C. A., \& Boshoff, C. (2002). Compensation, esteem valence and job performance: an empirical assessment of Alderfer's ERG theory. International Journal of Human Resource Management, 13(4), 697-719. http://dx.doi.org/10.1080/09585190210125868

[20] Amabile, T. M., Hill, K. G., Hennessey, B. A., \& Tighe, E. M. (1994). The Work Preference Inventory: assessing intrinsic and extrinsic motivational orientations. Journal of personality and social psychology, 66(5), 950. http://psycnet.apa.org/doi/10.1037/0022-3514.66.5.950

[21] Hogan, J. E., Lemon, K. N., \& Libai, B. (2003). What is the true value of a lost customer?. Journal of Service Research, 5(3), 196-208. http://psycnet.apa.org/doi/10.1177/ 10946705022 $\underline{38915}$

[22] Lee-Kelley, L., Gilbert, D., \& Mannicom, R. (2003). How e-CRM can enhance customer loyalty. Marketing Intelligence \& Planning, 21(4), 239-248. http://dx.doi.org/10.1108/ 026345003104 8 $\underline{0121}$

[23] Dhania, D. R. (2012). Pengaruh Stres Kerja, Beban Kerja, terhadap kepuasan Kerja (studi pada medical representatif di Kota Kudus). Jurnal Psikologi: PITUTUR, 1(1), 15-23.

[24] Abdullah, Zainuddin, (2012). Pengaruh Stres Kerja terhadap Kinerja Auditor melalui Motivasi Kerja Sebagai Variabel Intervening Studi Pada Auditor Intern di Pemerintah Provinsi Aceh. Jurnal Akuntansi Vol. 2, No. 1. Pp. 142-150

[25] Yozgat, U., Yurtkoru, S., \& Bilginoğlu, E. (2013). Job stress and job performance among employees in public sector in Istanbul: Examining the moderating role of emotional intelligence. Procedia-Social and behavioral sciences, 75,518-524.http://dx.doi.org/10.1016/ j.sbspro.2013. $\underline{04.056}$

[26] Arshadi, N., \& Damiri, H. (2013). The Relationship of Job Stress with Turnover Intention and Job Performance: Moderating Role of OBSE. Procedia-Social and Behavioral Sciences, 84, 706710.http://dx.doi.org/10.1016/j.sbspro.2013.06.631

[27] Spencer, L. M., \& Spencer, S. M. (1993). Competency at work. New York: John Wiely \& Sons.

[28] Numminen, O., Meretoja, R., Isoaho, H., \& Leino-Kilpi, H. (2013). Professional competence of practising nurses. Journal of clinical nursing, 22(9-10), 1411-1423.http://dx.doi.org/10.1111/ j.1365-2702.2012.04334.x

[29] Bendoly, E., \& Prietula, M. (2008). In "the zone": The role of evolving skill and transitional workload on motivation and realized performance in operational tasks. International Journal of Operations \& Production Management, 28(12), 1130-1152.http://dx.doi.org/10.1108/ $\underline{01443570810919341}$

[30] Bartram, T., \& Casimir, G. (2007). The relationship between leadership and follower in-role performance and satisfaction with the leader: the mediating effects of empowerment and trust in the leader. Leadership \& Organization Development Journal, 28(1), 4-19.http://dx.doi.org/ $\underline{10.1108 / 01437730710718218}$

[31] Widyatmini, W., \& Hakim, L. (2011). Hubungan kepemimpinan, kompensasi dan kompetensi terhadap kinerja pegawai dinas kesehatan kota depok. Jurnal Ilmiah Ekonomi Bisnis, 13(2).

[32] Usman, Husaini. (2006)."Manajemen." Teori, Praktek, dan Riset Pendidikan. Jakarta Bumi Aksara.

[33] Hakim, A. (2012). The Implementation of Islamic Leadership and Islamic Organizational Culture and Its Influence on Islamic Working Motivation and Islamic Performance PT Bank Mu'amalat Indonesia Tbk. Employee in the Central Java. Asia Pacific Management Review, 17(1), 78-91.

[34] Greenberg, Jerald and Baron, Robert A., (1997). Behavior in Organizations -Understanding and Managing the Human Side of Work, sixth edition, New Jersey:Prentice Hall

[35] Hartline, M. D., \& Jones, K. C. (1996). Employee performance cues in a hotel service environment: influence on perceived service quality, value, and word-of-mouth intentions. Journal of Business Research, 35(3), 207-215.http://dx.doi.org/10.1016/0148-2963(95)00126-3

[36] Purcărea, V. L., Gheorghe, I. R., \& Petrescu, C. M. (2013). The Assessment of Perceived Service Quality of Public Health Care Services in Romania Using the SERVQUAL Scale. Procedia Economics and Finance, 6, 573-585.http://dx.doi.org/10.1016/S2212-5671(13)00175-5 
[37] Padma, P., Rajendran, C., \& Lokachari, P. S. (2010). Service quality and its impact on customer satisfaction in Indian hospitals: Perspectives of patients and their attendants. Benchmarking: An International Journal, 17(6), 807-841. http://dx.doi.org/10.1108/14635771011089746

[38] Bodouva, J. J. (2009). The influence of employee perceptions of the work climate on perceived service quality and their relationships with employee goal orientations, employee self-efficacy, and employee job satisfaction. Nova Southeastern University.

[39] Tyrer, P. (1984). Psychiatric clinics in general practice. An extension of community care. The British Journal of Psychiatry, 145(1), 9-14. http://dx.doi.org/10.1192/bjp.145.1.9

[40] Kahn, R. L. \& Byosiere, P. (1992). Stress in organizations. In M. D. Dunnette \& L. M. Hough (Eds.), Handbook of industrial and organizational psychology (2nd ed., Vol. 3, pp. 571-650). Palo Alto, California: Consulting Psychologists Press

[41] Byars, L.L., and Rue, L.W. (1997) Human Resource Management. USA: Irwin/McGraw-Hill.

[42] Antonacopoulou, E. P., \& FitzGerald, L. (1996). Reframing competency in management development. Human Resource Management Journal, 6(1), 27-48

[43] Yang, G. F., \& Jiang, X. Y. (2014). Self-directed learning readiness and nursing competency among undergraduate nursing students in fujian province of China. International Journal of Nursing Sciences.1-5 http://dx.doi.org/10.1016/j.ijnss.2014.05.021

[44] Hsu, I. (2008). Knowledge sharing practices as a facilitating factor for improving organizational performance through human capital: A preliminary test. Expert Systems with applications, 35(3), $1316-1326$

[45] Dagger, T. S., Sweeney, J. C., \& Johnson, L. W. (2007). A hierarchical model of health service quality scale development and investigation of an integrated model. Journal of Service Research, 10(2), 123-142. ISO 690

[46] Robbins, Stephen P.(1996). Perilaku organisasi: Konsep, kontroversi dan aplikasi. (Jilid 1 dan 2) Edisi bahasa Indonesia. Alih bahasa: Pujaatmaka, H. Jakarta: Penerbit, PT Prenhallindo

[47] Stoner, J.A.F., R. Edward Freeman, Daniel R. Gilbert Jr. (1996). Management, 1th. Sindoro, A. (penerjemah). Manajemen. Prenhallindo.

[48] Amstrong, M. (2003). A handbook of human resource management practice. Kogan Page Limited.

[49] Chen, C. F., \& Kao, Y. L. (2014). Investigating the moderating effects of service climate on personality, motivation, social support, and performance among flight attendants. Tourism Management, 44, 58-66.

[50] Cash, W.H. and F.E. Fischer. (1987). Human Resource Planning.

[51] Clugston, M., Howell, J. P., \& Dorfman, P. W. (2000). Does cultural socialization predict multiple bases and foci of commitment?. Journal of management, 26(1), 5-30

[52] Vroom, V H. (1964). Work and motivation. New York: Wiley, .Carnegie Institute of Technology, Pittsburgh. PAJ.

[53] Liao, H., Toya, K., Lepak, D. P., \& Hong, Y. (2009). Do they see eye to eye? Management and employee perspectives of high-performance work systems and influence processes on service quality. Journal of Applied Psychology, 94(2), 371.

[54] Tjiptono, Fandy. (2005). Brand Management and Strategy. Yogyakarta: Penerbit Andi.

[55] Choi, K.S., Cho, W.H., Lee, S., Lee, H. \& Kim, C. (2004), the relationships among quality, value, satisfaction and behavioral intention in health care provider choice: a South Korean study, Journal of Business Research, 57(8). 913-921.

[56] Teas, R.K. (1993), "Expectations, performance evaluation and consumers' perception of quality”, Journal of Marketing, Vol. 57, October,. 18-34.

[57] Wilkinson, A., Allen, P., \& Snape, E. (1991). TQM and the management of labour. Employee Relations, 13(1), 24-31.

[58] Ali, M., \& Raza, S. A. (2015). Measurement of Service Quality Perception and Customer Satisfaction in Islamic Banks of Pakistan: Evidence from Modified SERVQUAL Model.

[59] Robbins, S.P. (2003). Organisational behaviour (10th Ed). San Diego: Prentice Hall 
[60] Heidjrachman \& Suad Husnan, (2000), Manajemen Personalia, Edisi 4, Cetakan Kesembilan, BPFE, Yogyakarta

[61] Kock, N. (2010). Using WarpPLS in e-collaboration studies: An overview of five main analysis steps. International Journal of e-Collaboration (IJeC), 6(4), 1-11.

[62] Kock, N. (2011). Using WarpPLS in e-collaboration studies: Descriptive statistics, settings, and key analysis results. International Journal of e-Collaboration, 7(2), 1-17.

[63] Hair, J. F., Ringle, C. M., \& Sarstedt, M. (2013). Editorial-partial least squares structural equation modeling: Rigorous applications, better results and higher acceptance. Long Range Planning, 46(1-2), 1-12.

[64] Sholihin, M \& Dwi R. (2013). Analisis SEM-PLS dengan WarpPLS 3.0. Andi. Yogyakarta

[65] Kock, N. (2013). Using WarpPLS in E-Collaboration Studies: Descriptive Statistics, Settings. Interdisciplinary Applications of Electronic Collaboration Approaches and Technologies, 62.

\section{AUTHOR'S BIOGRAPHY}

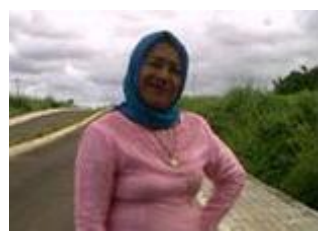

Mariana Tenreng

Institutions: University of East Indonesia, Makassar

Affiliation: Management 